\title{
Information Content of Earnings Opacity on Firm Value
}

\author{
Omar Camara \\ Department of Accounting and Finance, College of Business Administration (COBA) \\ Prince Mohammad Bin Fahd University, Saudi Arabia \\ E-mail: ocamara@hotmail.com
}

Received: March 2, 2018

Accepted: March 27, 2018

Published: March 28, 2018

doi:10.5296/ijafr.v8i1.12906

URL: https://doi.org/10.5296/ijafr.v8i1.12906

\begin{abstract}
This study use a panel data set of balance sheet and income statement of US firms within manufacturing and services industries for the period 1987-2015 to examine the impact of two dimensions of earnings opacity on firm value - earnings aggressiveness (i.e. measured by accounting accruals) and earnings smoothing (i.e. measured by the correlation between accruals and operating cash flows). Specifically, the paper investigate if earnings opacity affects equity markets and if there is a differential effect of earnings opacity on equity markets across manufacturing and services industries. Information asymmetry in contract theory and economics expound on the positive role of information in averting price disequilibrium in the capital markets and a potential capital market failures due to an imbalance in accessing information. A capital market sufficiently characterized by efficiency and informational symmetry is expected to embody distinctive qualities in facilitating accurate interpretation of market relevant information and a subsequent timely re-evaluation of prior equity valuations. The empirical results of these panel data tests, after controlling for key influencers on equity price, shows that on average, an increase in earnings opacity is linked to an increase in market value for firms within the manufacturing industry. In contrast, the results shows that on average, an increase in earnings opacity leads to a decrease in market value for firms within the services industry. Furthermore, the results suggest that firms utilize both dimensions of earnings opacity in a sustained manner as implied by the coefficients on time-trend and the interaction of time-trend and earnings opacity.
\end{abstract}

Keywords: Earnings opacity, Capital markets, Financial reporting, Firm value, Market efficiency

JEL Classification: F00; F30; G15, G30, M41 


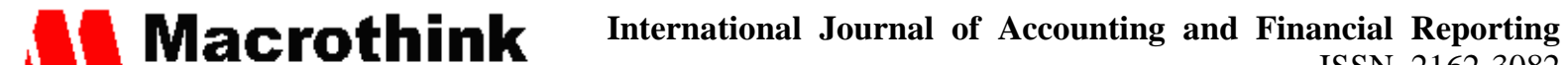 ISSN 2162-3082 2018, Vol. 8, No. 1}

\section{Introduction}

The objective of this paper is to determine the impact of earnings opacity on the equity market value of firms within the manufacturing and services industries. An industry approach in this paper is in recognition of the accounting- induced differentiation in the revenue generating processes - certain accounting treatments are industry-specific. To be precise, I explore whether accruals and earnings smoothing (earnings opacity measures) are accurately and timely detected by investors in firms within manufacturing and services industry. Bhattacharya et.al (2003) describes earnings opacity as a phenomenon that obscures relevant information about a firm's true underlying economic performance. This description of earnings opacity by Bhattacharya et. al (2003) is not inconsistent with the statement by Ball et al (2000), that earnings transparency (opposite of earnings opacity) is when unobservable economic income is timely incorporated into accounting earnings. Similarly, Healey and Wahler (1999) described earnings opacity as the alteration or design of a firm's reported economic performance by insiders to either "mislead some stakeholders" or "to influence contractual outcome". Incidentally, both accounting accruals and earnings smoothing used as measures of earnings opacity in this paper can be employed as tools to veil the true economic performance of a firm. Indeed it is reasonable to assert that the existence and necessity of auditing profession is to infuse confidence in financial statements, enabling the auditors to act as modulating forces against earnings opacity practices. Earnings of firm's may not be transparent for many reasons ranging from managerial incentives (Shivakumar, 2000; Barth el al, 1999) to flexibility in accounting standards (Dye and Sridhar, 2008), thus in this paper, I do not focus on the inherent complexities of identifying the causes or motivations of earnings opacity but to rather explore the statistical properties of announced financial data in order to determine the reaction of the market participants to earnings opacity as manifested in equity prices.

Hence earnings opacity decouples reported accounting earnings from the true economic earnings, prior literature has identified accounting accruals and earnings smoothing among others as a proxy for earnings opacity. Accounting conservatism as bedrock of US accounting standards predicated earlier recognition of losses and delayed recording of gains in order to minimize informational gap. From that perspective, accounting accruals is used in this paper as the first proxy for earnings opacity. Moreover, it is a well established notion that financial markets tend to attach a high value premium to stability and continuity of earnings; thus investors are presumed to be delicate to unexpected oscillations in reported earnings. As such managers may be inclined to shift earnings (Trueman and Titman, 1988; Fudenberg and Tirole, 1995) from one period to another in order to portray steady and predictable growth in earnings. Such managerial effort may potentially effect investor sentiment and ensure equity price stability. Given the aforementioned accounting paradigms within the broader financial reporting landscape, this paper utilizes earnings smoothing measure as the second proxy for earnings opacity. The contribution of this paper to the literature is that it is the first paper to my knowledge that measures earnings opacity at industry level by using a panel data to assess the effect of earnings opacity on firm market value. 


\section{MlMacrothink}

International Journal of Accounting and Financial Reporting

ISSN 2162-3082

2018, Vol. 8, No. 1

The paper proceeds as follows. Section 2 reviews the literature. Section 3 introduces data and methodology. Section 4 presents the results, and section 5 concludes the paper.

\section{Literature Review}

As part of a growing accounting literature, researchers have examined the value relevance of accounting measures to equity market (Ali and Hwang (2000), Land and Lang (2002)), analyst forecasts (Ashbaugh and Pincus (2001), Chang et al. (2000)), timeliness of earnings and conservatism (Ball et al. (2000)), or the impact of institutional variables on earnings management (Leuz et al. (2001).) In addition, an increasing body of literature has established a preponderant role of asymmetric information in the equity markets (Gehrig (1993), Brennan and Cao (1997)). More recently, Portes et al. (2001), using a gravity model, reported that informational asymmetries are key determinants of international transactions in financial assets.

Since the Enron debacle and other high profile accounting malfeasance in US in 2000, coordinated regulations, including expanded disclosure acts were enacted by US congress to minimize the risk of accounting shenanigans. However, it is well understood that regulations alone will not guarantee complete immunization from earnings opacity. Indirectly referring to earnings opacity, Kothari and Robin (2000) argue that accounting conservatism is positively related to accounting transparency (i.e. opposite of earnings opacity). Bekaert and Harvey (2000) explore in great detail the relationship between dividend yields and the cost of equity. Both in theory and practice, earnings opacity may influence dividend yields, which in turn may influence equity market valuation. The timely detection of such pass-through linkage between earnings opacity and equity price partially depends on the severity of informational asymmetry, market efficiency, and the degree of investor sophistication. To this effect, Heath and Tversky (1991) affirm that "... holding judged probability constant; people prefer to bet in a context where they feel ignorant and uninformed". Furthermore, Bhattacharya et al. (2003) stated that, an apparent manifestation of low level of accounting quality is the high level of earnings opacity. Perpetuation of earnings opacity is consistent with rational conditions, particularly in a financial market that rewards firms with predictable patterns of increasing earnings (Barth, el al. 1999, Degeorge, F, J. Patel, and R. Zeckhauser. 1999, Healey, P., and J. Wahlen. 1999). The motivational factor for management's earnings opacity practices varies and may be strictly circumstantial. For example, Healy (1985) finds a positive link between bonus schemes and accounting decisions, while Rangan (1998) shows a relationship between earnings management practices and the performance of seasoned equity offerings. Shivakumar, L. (2000) also studied the overstatement of earnings prior to seasoned equity offerings. In contrast to the relationship between earnings opacity and seasoned offerings, Teoh, S. H et.al (2002) shows that high accrual firms tend to underperform with new equity offerings. From the above prior studies, it is obvious that accounting measures have value relevance in the financial markets. The contribution of my paper to the literature is that it is the first paper to my knowledge that measures earnings opacity at industry level by using a panel data to assess the effect of earnings opacity on firm market value. I took the investor perspective in the interpretation of the assessed effect of earnings opacity on market 
value - that is whether investors of manufacturing and services industry accurately and timely detect and therefore attach earnings opacity premium to equity prices.

\section{Data and Methodology}

All annual firm level data used in constructing the two earnings opacity variables - earnings aggressiveness and earnings smoothing, and other control variables come from the Compustat-CRSP database for the years 1987 through 2015. Due to continuous data unavailability, I restrict the sample to two US industries (SIC codes 2000-3999 and SIC codes 7000-8999). Since the underlying earnings generating process and the industry accounting practices are similar for firms within the industry, I ran a pooled regression including an industry dummy variable in table 3 and 4 to ensure that the inferences from the pooled sample are statistically and meaningfully different from individual industry regressions due to industry specific characteristics. In order to minimize spurious relationship, I include firms which have data for more than ten consecutive years. This yields a total of 30,854 firm-year observations before trimming the data at upper and lower $1 \%$, and prior to calculation of accruals and cash flows which requires data from year $\mathrm{t}-1$. The final sample data has 25,863 firm-year observations of which manufacturing industry represents 20,158 firm-year observation and the remaining 5,705 firm-year observations represents services industry. Similar to Leuz et al. (2003), if input variables are missing, I assume the value to be zero.

Following Healy (1985), and Leuz et al. (2003), I used scaled accruals to measure earnings aggressiveness from balance sheet and income statement information as follows:

$$
\text { Accruals }_{i t}=\left(\frac{\Delta T C A_{i t}-\Delta T C L_{i t}-\Delta L I Q_{i t}+\Delta C P L T_{i t}-A_{T T R I T I O N}+\Delta T L_{i t}}{T A_{i t-1}}\right)
$$

Where

$\Delta T C A_{i t}=$ Change in total current assets for firm $i$ at time $t$

$\Delta T C L_{i t}=$ Change in total liabilities for firm $\boldsymbol{i}$ at time $\boldsymbol{t}$

$\Delta L I Q_{i t}=$ Change in cash for firm $i$ at time $t$

$\triangle C P L T_{i t}=$ Change in current portion of long-term debt for firm $\boldsymbol{i}$ at time $\boldsymbol{t}$

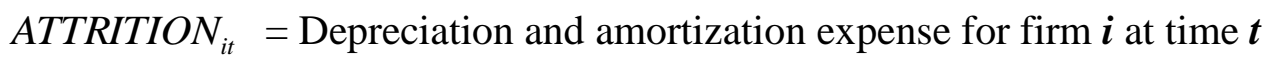

$\Delta T L_{i t}=$ Change in income taxes payable for firm $i$ at time $t$

$T A_{i t-1}=$ Total assets for firm $\boldsymbol{i}$ at time $\boldsymbol{t}-\mathbf{1}$ 


\section{MIMacrothink}

International Journal of Accounting and Financial Reporting

ISSN 2162-3082

2018, Vol. 8, No. 1

The scaled accrual defined above is used along with other salient accounting variables in order to examine the marginal effect of earnings aggressiveness on the market value of firms across the manufacturing and services industry. In addition to earnings aggressiveness, I examined the second dimension of earnings opacity - earnings smoothing (i.e. a proxy for earnings management) on market capitalization. Generally, earnings smoothing allows earnings to obscure the underlying volatility of the firm's economic performance. A two stage derivation approach is used to compute earnings smoothing. At first stage, I followed the methodology of Flannery et al. (2011) to derive firm's operating cash flow as follows:

$$
\text { CashFlows }_{i t}=\frac{O I_{i t}-\text { Tax }_{i t}-\text { IntPaid }_{i t}}{T A_{i t-1}}-\text { CapEx }_{-} \text {Industry }_{i t}
$$

Where

$\mathrm{OI}_{\mathrm{it}}$ is the operating income before depreciation

$\operatorname{Tax}_{i t}$ is the total taxes reported on the income statement

IntPaid $_{i t}$ is the interest paid

$\mathrm{TA}_{\mathrm{it}-1}$ is the lagged total book assets

CapEx_Industry ${ }_{i t}$ is the industry mean value of capital expenditure in year $t$ scaled by lagged total book assets.

At the second stage given the first stage, I followed the methodology of Leuz et al. (2003) by defining earnings smoothing as a correlation between the change in accruals and the change in cash flows, both scaled by lagged total assets for firm $i$, in year $t$ as follows:

$$
E S=\frac{n\left(\sum \Delta A c c r_{i t} \Delta C F_{i t}\right)-\left(\sum \Delta A c c r_{i t}\right)\left(\sum \Delta C F_{i t}\right)}{\left[n \sum \Delta A c c r_{i t}{ }^{1 / 0.5}-\left(\sum \Delta A c c r_{i t}\right)^{1 / 0.5}\right]^{0.5}\left[n \sum \Delta C F_{i t}{ }^{1 / 0.5}-\left(\sum \Delta C F_{i t}\right)^{1 / 0.5}\right]^{0.5}}
$$

Where

$\mathrm{ES}=$ Earnings Smoothing

$\Delta$ Accr $_{i t}=$ changes in Accruals for firm $i$ at time $t$

$\Delta C F_{i t}=$ changes in Cash flows for firm $i$ at time $t$

Prior papers in this strand of literature used either market returns (Chen and Zhang, 2007) or market capitalization (Easton and Harris, 1991) as a dependent variable for changes in firm value; As such I employed level market capitalization as the explained variable by adopting the additive linear model of Barth et al. (1998) in equation 4, and market returns formulations, known as the "deflated" additive model of Easton and Harris (1991) in equation 5 (i.e. Due to lack of dividend data, I did not adjust the returns by dividend) is used to estimate the effect of 


\section{Mll Macrothink}

International Journal of Accounting and Financial Reporting

ISSN 2162-3082 2018, Vol. 8, No. 1

earnings aggressiveness and earnings smoothing on firm's value. Model 5 addresses the perceived scale problem in the levels regressions as recommended by Christie (1987) and further argued by (Barth \& Kallapur, 1996; Kothari \& Shanken, 1997, 2003). Notably, market model was also used among others by (Chen \& Zhang, 2007; Fama \& French, 1992)

$$
\begin{gathered}
M_{i t}=z_{i t}+v_{i t} K_{i t}+\phi I N D+\varepsilon_{i t} \\
\frac{M_{i t}}{M_{i t-1}}=Z_{i t}^{\prime}+v_{i t}^{\prime} \frac{K_{i t}}{M_{i t-1}}+\phi I N D+\varepsilon_{i t}
\end{gathered}
$$

$M_{i t}$ is the market value of firm $\boldsymbol{i}$ at time $\boldsymbol{t} ; K_{i t}$ is a vector of accounting variables of firm $\boldsymbol{i}$ at time $t$; the estimates of the parameters $z, v, Z^{\prime}$, and $v^{\prime}$ are vectors of coefficients; and $\varepsilon_{i t}$ is the white noise error term. To further examine whether there is a trend and timing element to firm's earnings aggressiveness and earnings smoothing practices, model 6 and 7 includes the time trend $t$ and the interaction between time trend and the two earnings opacity measures tx as follows:

$$
\begin{gathered}
M_{i t}=z_{i t}+v_{i t} K_{i t}+\lambda t+\gamma(t x)+\varepsilon_{i t} \\
\frac{M_{i t}}{M_{i t-1}}=Z_{i t}^{\prime}+v_{i t}^{\prime} \frac{K_{i t}}{M_{i t-1}}+\lambda t+\gamma(t x)+\varepsilon_{i t}
\end{gathered}
$$

Where

$\lambda$ is the coefficient on time trend $t$ with the definition of $\frac{\partial M_{i t}}{\partial t}$ in eq. 6 and $\frac{\left(\partial \frac{M_{i t}}{M_{i t-1}}\right)}{\partial t}$ in eq.7; $t x$ is the interaction between time trend $t$ and earnings opacity $x$.

\section{Results}

As can be seen from the descriptive information in Table 1, there are significant variations in earnings opacity variables for manufacturing and services industries. These differences may be associated with dissimilarities in industry characteristics, not simply by dint of earnings opacity. As anticipated, in table $1 \mathrm{~b}$ and $1 \mathrm{c}$, average accruals are negative, averaging about $6 \%$ and $1 \%$ of lagged total assets for manufacturing and services industries respectively. Curiously, average earnings smoothing is positive for manufacturing industry, but negative for services industry as anticipated.

In Table 2, the correlation between accruals and earnings smoothing is negative. The negative correlation is expected because earnings smoothing materialized to some extent in reaction to the accrual-based accounting process which inherently accommodates considerable level of 


\section{MInstitute Macrothink $_{\text {Int }}^{\text {Intis }}$}

International Journal of Accounting and Financial Reporting

ISSN 2162-3082

2018, Vol. 8, No. 1

flexibility in accounting treatments, particularly in the sphere of accounting estimates, allowances and reversals. As expected, control variables in the correlation matrix in table 2, shows opposing correlation signs with the two earnings opacity measures.

Figure 1 shows level of earnings smoothing on the distribution of accounting earnings over the sample period. It can be seen in graph 2 of figure 1 that on average, firms within the manufacturing industry smooth earnings within a wider space (-.48 to .5$)$ than firms within services industry (-.2.3 to .2) in graph 3 . Such graphical information provides an insight to the empirical results in table 3 . It can be argued that, in contrast to services industry, the wider operating space for accruals within the manufacturing industry increases information asymmetry and therefore pose a challenge for accurate and timely detection by investors. This reasoning appears to be substantiated in table 3 showing a positive (i.e. wrong sign) and statistically significant at $1 \%$ level for earnings smoothing. Suggesting that investors instead of demanding earnings opacity premium are rewarding these firms. Graph 3 is consistent with Table 3 in suggesting that firms within the services industry tend not to engage in wider scale earnings smoothing due to its negative impact on firm value. Moreover, Figure 1 and Table 3, demonstrated that on average, investors in services industry are relatively able to detect and priced into equity-value the uncertainty induced by earnings smoothing. In Figure 2, graphs 5 and 6 , in conjunction with tables $1 \mathrm{~b}$ and $1 \mathrm{c}$, shows that accruals over the sample period for manufacturing industry are relatively more disperse than in services industries. A cursory view of graph 5 shows that earlier period of the sample has an inordinate influence on the dispersion of accruals for manufacturing industry. In graph 5, on average from period $2004-$ 2015, accruals for manufacturing firms relatively decline from one period to another, implying an increasingly inflated reported earnings and deflated liabilities.

Table 3 presents the results of ordinary least squares (OLS) regression using level market value. In this and succeeding empirical tests, I explore the effect of earnings opacity on two dimensions of equity market for manufacturing and services industry - the level average market value of firms (models 4 and 6) and the return to market value (i.e. excluding dividends) in a form of scaled market capitalization (models 5 and 7). After controlling for industry, and other variables known in the literature to have some influence on earnings opacity, the coefficient of earnings smoothing (earnings opacity measure) in model 4 is positive and statistically significant at $1 \%$ level for manufacturing industry, and negative and statistically significant at $1 \%$ level for services industry. However, the coefficient of accruals (earnings opacity measure) shows no statistical significance for both manufacturing and services industry. For control variables, the coefficients of return on assets (ROA) and earnings before interest, depreciation and amortization (EBITDA) on level market value, as expected, are positively and statistically significant for both industries. In this study, a positive and statistically significant coefficient on earnings opacity measures (accruals and earnings smoothing) means that an increase in earnings opacity is associated with an increase in firm value in the stock market irrespective of whether firm value is measured as total market capitalization (level market value) or as a market return (scaled market value). This association is consistent with the implications of information asymmetry and inefficient 
market in which equity mispricing is highly probable, due among other factors, to lack of detection of earnings opacity.

In Table 4, market return (scaled market value) measurement is used to examine the impact of earnings opacity. Interestingly, using this measurement, investors of manufacturing industry appears indifferent to earnings, whilst the investors of services industry appear to detect the adverse implications of accruals. Nevertheless, the same investors of services firms were unable or have misinterpreted earnings smoothing. Notably, earnings opacity of manufacturing industry consistently appears to be relatively receptive to level market value measurement than market return measurement, whilst services industry is relatively receptive to market return (scaled market value) measurement than level market value measurement.

In Tables 5, 6 and 7, the coefficient on time-trend is positively and statistically significant at $1 \%$ level and the coefficient on the interaction of time-trend and accruals is negative and statistically significant at 1 percent level. This suggests undetected earnings opacity at a point in time followed by a correction over time by investors of manufacturing firms. Again, this is in contrast to the investors of services firm as report in Table 6. The time trend and its interaction with earnings smoothing in Table 7 suggest immediate detection by both investors of manufacturing and services firms, however the interaction of time trend and earnings smoothing were subsequently misinterpreted by investors of services firms.

Table 1a. Earnings Opacity Measures (*) \& Control Variables

\section{Summary Statistics - Pooled}

\begin{tabular}{lccccc} 
Variables & \# of Obs & Mean & Std. Dev. & Min & Max \\
\hline Accruals $(*)$ & 25863 & -4.474 & 870.213 & -137941 & 23602.46 \\
Smoothing $(*)$ & 25863 & -.0003 & .2679 & -.9899 & .9996 \\
ROA & 25863 & -.0133 & .4009 & -27.58 & 2.5488 \\
ROS & 25863 & -1.6193 & 49.856 & -4939.75 & 609.07 \\
EBITDA & 25863 & 575.994 & 2499.357 & -2214 & 81730 \\
MV & 25863 & 4772.788 & 19712.32 & .0727 & 647506 \\
Scaled MV & 25863 & 1.2890 & 1.6722 & .0046 & 140.6651 \\
\hline
\end{tabular}

Table 1b. Earnings Opacity Measures (*) \& Control Variables

\begin{tabular}{lccccc}
\hline \multirow{2}{*}{ Variables } & \multicolumn{7}{c}{ Summary Statistics - Manufacturing } & & \\
\cline { 2 - 5 } & \# of Obs & Mean & Std. Dev. & Min & Max \\
\hline Accruals $\left(^{*}\right)$ & 20158 & -5.7204 & 985.6925 & -137941 & 23602.46 \\
Smoothing $\left(^{*}\right)$ & 20158 & .0020 & .2623 & -.9899 & .9996 \\
ROA & 20158 & -.0135 & .4142 & -27.5752 & 2.5488 \\
ROS & 20039 & -1.9538 & 55.6821 & -4939.75 & 21.8464 \\
EBITDA & 20158 & 636.9545 & 2722.443 & -2214 & 81730 \\
MV & 20133 & 5237.684 & 21170.82 & .1804 & 647506.9 \\
Scaled MV & 18959 & 1.2708 & 1.2162 & .0056 & 49.4330 \\
\hline
\end{tabular}




\section{Macrothink \\ International Journal of Accounting and Financial Reporting ISSN 2162-3082 2018, Vol. 8, No. 1}

Table 1c. Earnings Opacity Measures (*) \& Control Variables

\begin{tabular}{lccccc}
\hline \multirow{2}{*}{ Variables } & \multicolumn{2}{c}{ Summary Statistics - Services } & & \\
\cline { 2 - 6 } & \# of Obs & Mean & Std. Dev. & Min & Max \\
\hline Accruals $\left(^{*}\right)$ & 5705 & -.0714 & 3.1999 & -214.815 & 14.3811 \\
Smoothing $\left(^{*}\right)$ & 5705 & -.0085 & .2869 & -.9587 & .9134 \\
ROA & 5705 & -.0128 & .3499 & -12.3310 & 1.6757 \\
ROS & 5693 & -.4417 & 17.8799 & -863.15 & 609.0735 \\
EBITDA & 5705 & 360.5964 & 1439.356 & -622.541 & 25849 \\
MV & 5695 & 3129.288 & 13204.29 & .0727 & 314623.5 \\
Scaled MV & 5310 & 1.3539 & 2.7375 & .0046 & 140.6651 \\
\hline
\end{tabular}

Table 2. Relation between Earnings Opacity Measures (8) \& Control Variables

\begin{tabular}{lcccccr}
\hline \multicolumn{7}{c}{ Correlation Matrix } \\
\hline & Smoothing & ROA & ROS & EBITDA & MV & S.MV \\
\hline Accruals $\left(^{*}\right)$ & -0.011 & 0.013 & -0.011 & 0.003 & 0.004 & -0.168 \\
Smoothing $\left(^{*}\right)$ & 1 & -0.014 & 0.001 & -0.019 & -0.005 & 0.013 \\
ROA & & 1 & 0.139 & 0.067 & 0.077 & -0.025 \\
ROS & & & 1 & 0.008 & 0.007 & -0.029 \\
EBITDA & & & & 1 & 0.868 & -0.021 \\
MV & & & & & 1 & -0.010 \\
Scaled MV & & & & & & 1 \\
\hline
\end{tabular}
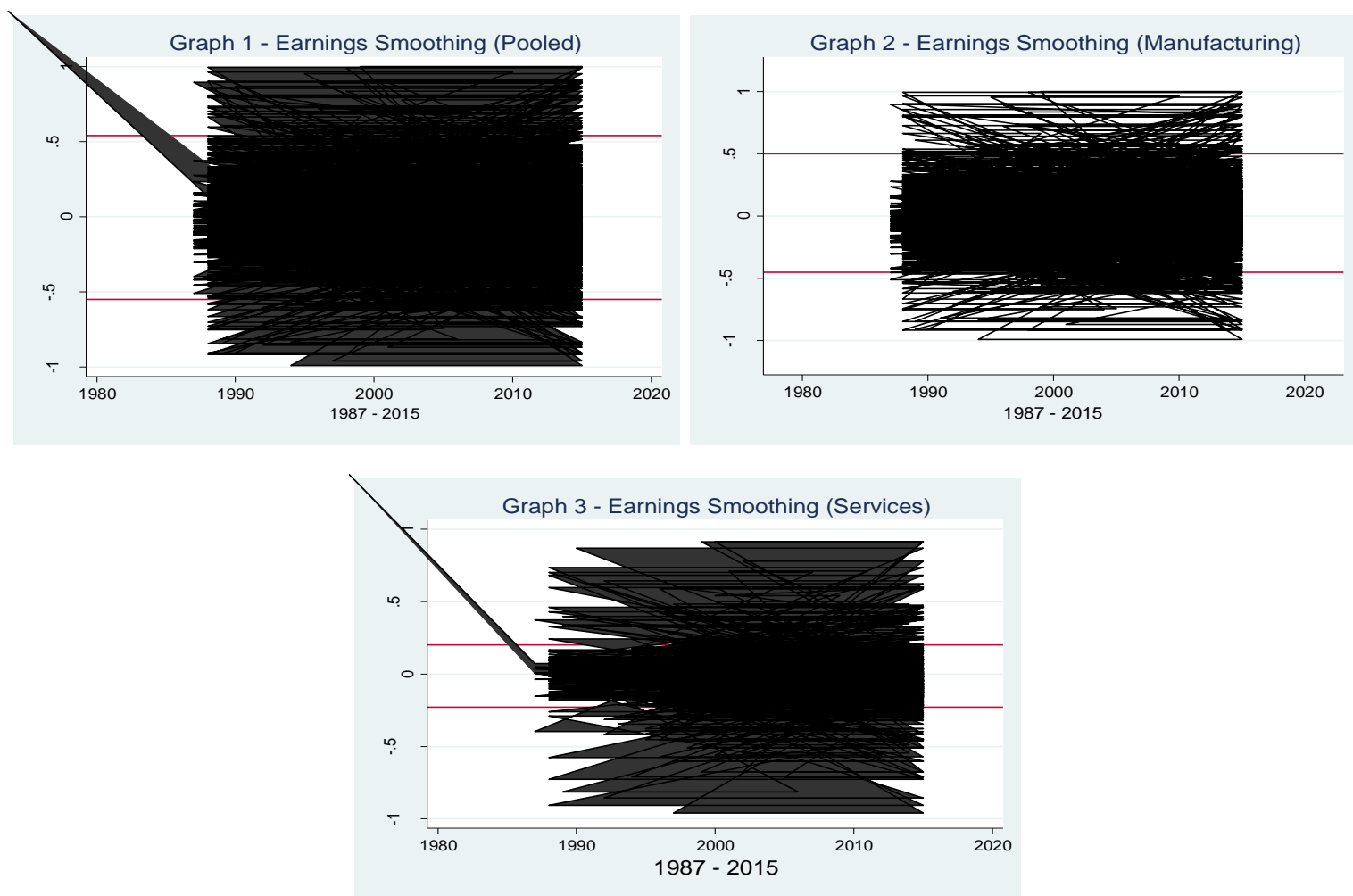

Figure 1. Time-Series Behaviour of Earnings Opacity Variable - Earnings Smoothing 


\section{Macrothink}

International Journal of Accounting and Financial Reporting ISSN 2162-3082

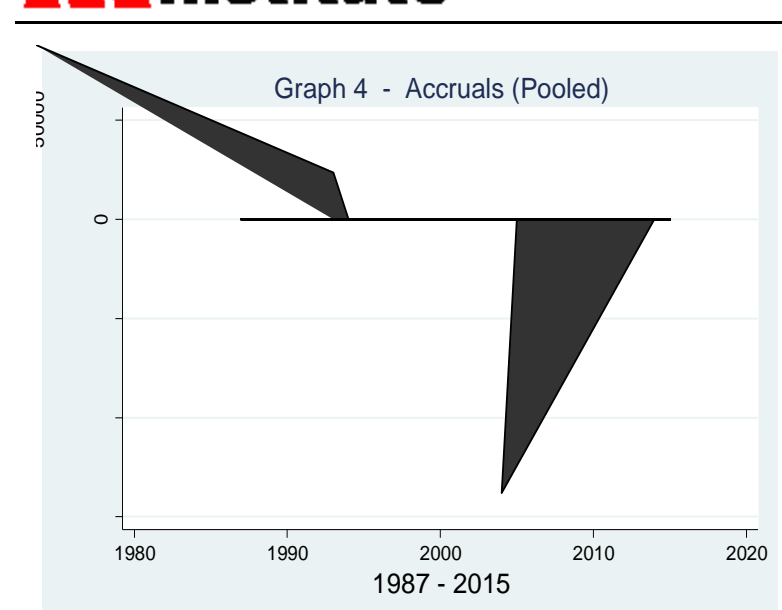
2018, Vol. 8, No. 1
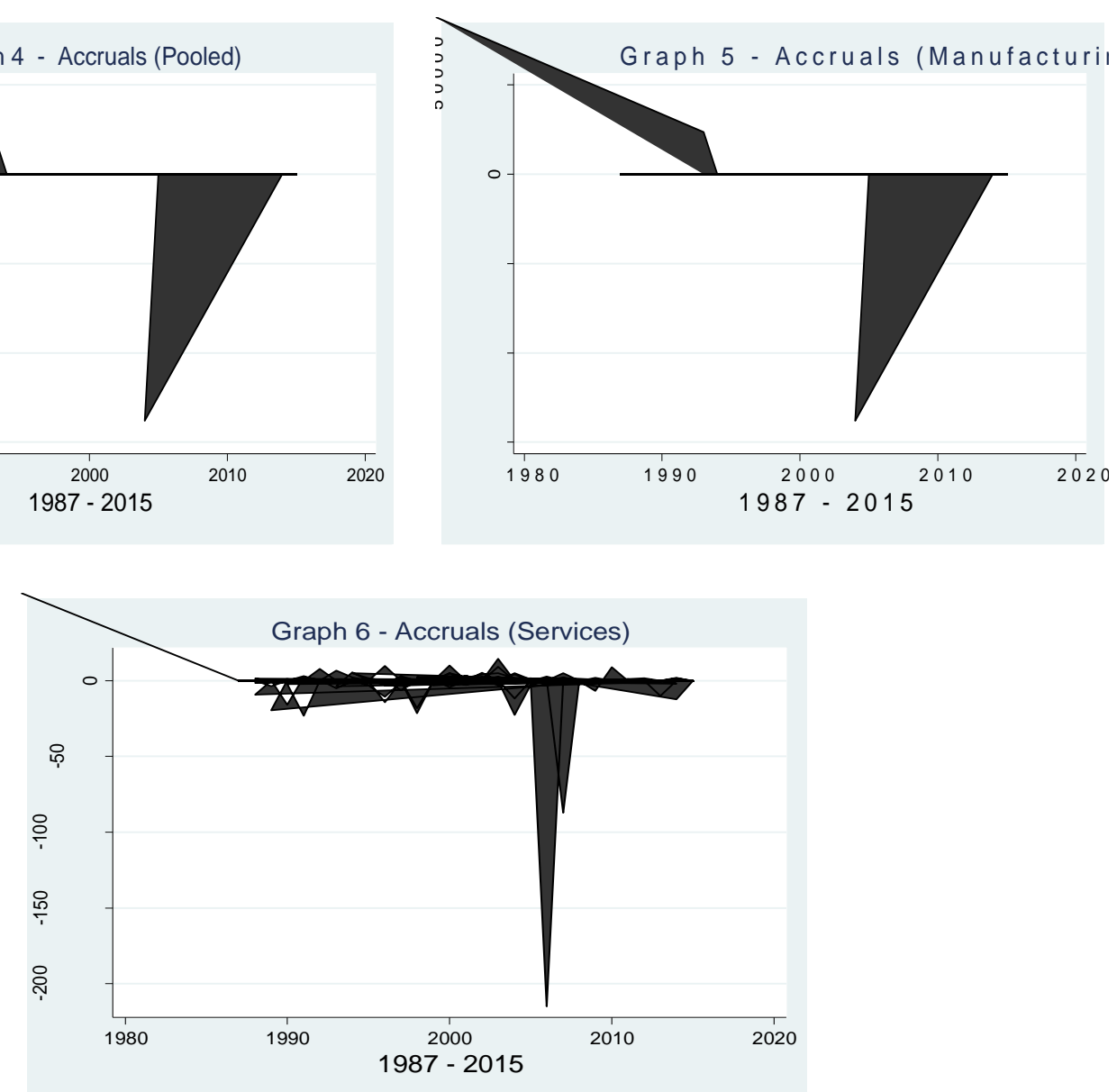

Figure 2. Time-Series Behaviour of Earnings Opacity Variable - Accruals

Table 3. Effect of Earnings Opacity on Firm Value

Model (4): $M_{i t}=z_{i t}+v_{i t} K_{i t}+\phi I N D+\varepsilon_{t}$ OLS regression with robust standard errors in bracket $(\mathrm{n} /(\mathrm{n}-\mathrm{k}))$.*;**;*** denotes $1 \%, 5 \%$ and $10 \%$ significance respectively.

\begin{tabular}{lccc}
\hline & Pooled & Manufacturing & Services \\
\hline Accruals & $.004(.005)$ & $.003(.004)$ & $-.8563(2.895)$ \\
Earnings Smoothing & $784.44(226.94)^{*}$ & $1180.48(302.26)^{*}$ & $-615.90(127.82)^{*}$ \\
ROA & $1204.12(200.23)^{*}$ & $1430.10(267.38)^{*}$ & $465.86(255.30)^{* * *}$ \\
ROS & $-.682(.399)^{* * *}$ & $-.7206(.4376)$ & $-2.822(1.61)^{* * *}$ \\
EBITDA & $6.84(.215)^{*}$ & $6.7473(.2285)^{*}$ & $8.06(.314)^{*}$ \\
IND & $197.82(104.68)^{* * *}$ & - & - \\
Cons & $680.89(112.03)^{*}$ & $940.10(103.98)^{*}$ & $217.71(80.55)^{*}$ \\
R $^{2}$ & 0.7563 & 0.7560 & 0.7744 \\
F-Statistics: Prob>F & 0.0000 & 0.0000 & 0.0000 \\
\# of Obs. & 25,701 & 20,018 & 5,683 \\
\hline
\end{tabular}




\section{Macrothink \\ International Journal of Accounting and Financial Reporting ISSN 2162-3082}

Table 4. Effect of Earnings Opacity on Firm Value (Scaled)

Model (5): $\frac{M_{i t}}{M_{i t-1}}=Z_{i t}^{\prime}+v_{i t}^{\prime} \frac{K_{i t}}{M_{i t-1}}+\phi I N D+\varepsilon_{t}$ OLS regression with robust standard errors in bracket $(\mathrm{n} /(\mathrm{n}-\mathrm{k})) . * ; * ; * * *$ denotes $1 \%, 5 \%$ and $10 \%$ significance respectively.

\begin{tabular}{cccc}
\hline & Pooled & Manufacturing & Services \\
\hline Accruals & $-1.37(.665)^{* *}$ & $.003(.216)$ & $-1.40(.758)^{* * *}$ \\
Earnings Smoothing & $7.32(3.44)^{* *}$ & $.434(.797)$ & $8.44(4.28)^{* *}$ \\
ROA & $-1.75(2.11)$ & $-1.50(1.47)$ & $-3.46(5.41)$ \\
ROS & $-.217(.146)$ & $-.103(.109)$ & $-.343(.539)$ \\
EBITDA & $.209(.197)$ & $.705(.193)^{*}$ & $.162(.135)$ \\
IND & $-.049(.027)^{* * *}$ & - & - \\
Cons & $1.27(.041)^{*}$ & $1.15(.028)^{*}$ & $1.26(.033)^{*}$ \\
$\mathrm{R}^{2}$ & 0.2647 & 0.0502 & 0.4506 \\
F-Statistics: Prob>F & 0.0809 & 0.0132 & 0.0943 \\
\# of Obs. & 24,160 & 18,861 & 5,299 \\
\hline
\end{tabular}

Table 5. Effect of Earnings Opacity on Firm Value

Model (6): $M_{i t}=z_{i t}+v_{i t} K_{i t}+\lambda t+\gamma(t x)+\varepsilon_{i t}$ FGLS with robust standard errors in bracket $(\mathrm{n} /(\mathrm{n}-\mathrm{k})) . * * * * * * *$ denotes $1 \%, 5 \%$ and $10 \%$ significance respectively.

\begin{tabular}{lccc}
\hline & Pooled & Manufacturing & Services \\
\hline Accruals & $.073(.017)^{*}$ & $.085(.019)^{*}$ & $-8.26(9.26)$ \\
ROA & $306.8(121.9)^{* *}$ & $333.69(151.2)^{* *}$ & $327.4(221.26)$ \\
ROS & $.075(.093)$ & $.113(.114)$ & $-.740(.622)$ \\
EBITDA & $6.39(.639)^{*}$ & $6.32(.668)^{*}$ & $7.645(.365)^{*}$ \\
$\lambda$ & $96.18(22.90)^{*}$ & $112.59(25.69)^{*}$ & $4.982(10.97)$ \\
$\lambda(t x)$ & $-.005(.001)^{*}$ & $-.005(.001)^{*}$ & $.452(.502)$ \\
$\mathrm{R}^{2}$ & & & .7743 \\
F-statistics. & .7567 & .7565 & $134.86(0.0000)^{*}$ \\
\hline
\end{tabular}




\section{Macrothink \\ International Journal of Accounting and Financial Reporting ISSN 2162-3082 2018, Vol. 8, No. 1}

Table 6. Effect of Earnings Opacity (Accruals) on Firm Value (Scaled)

Model (7): $\quad \frac{M_{i t}}{M_{i t-1}}=Z_{i t}^{\prime}+v_{i t}^{\prime} \frac{K_{i t}}{M_{i t-1}}+\lambda t+\gamma(t x)+\varepsilon_{i t} \quad$ FGLS with robust standard errors in bracket (n/(n-k)). $* ; * * ; * *$ denotes $1 \%, 5 \%$ and $10 \%$ significance respectively.

\begin{tabular}{lccc}
\hline & Pooled & Manufacturing & Services \\
\hline Accruals & $2.55(1.67)$ & $-.549(.384)$ & $5.91(162)^{*}$ \\
ROA & $1.25(2.17)$ & $-1.89(.917)^{* *}$ & $-1.07(3.43)$ \\
ROS & $-.227(.121)^{* * *}$ & $-.089(.079)$ & $-.314(.206)$ \\
EBITDA & $.129(.149)$ & $.974(.232)^{*}$ & $.058(.089)$ \\
$\lambda$ & $-.009(.001)^{*}$ & $-.004(.001)^{*}$ & $-.016(.003)^{*}$ \\
$\lambda(t x)$ & $-.196(.098)^{* *}$ & $.069(.057)$ & $-.374(.099)^{*}$ \\
& & & \\
$\#$ of obs. & & & 5,299 \\
$\mathrm{R}^{2}$ & 24,160 & 18,861 & .4394 \\
F-statistics. & .2356 & .0514 & $65.82(0.0000)^{*}$ \\
\hline
\end{tabular}

Table 7. Effect of Earnings Opacity (Earnings Smoothing) on Firm Value (Scaled)

Model (7): $\quad \frac{M_{i t}}{M_{i t-1}}=Z_{i t}^{\prime}+v_{i t}^{\prime} \frac{K_{i t}}{M_{i t-1}}+\lambda t+\gamma(t x)+\varepsilon_{i t}$ FGLS with robust standard errors in bracket (n/(n-k)). $* ; * * * * *$ denotes $1 \%, 5 \%$ and $10 \%$ significance respectively

\begin{tabular}{lccc}
\hline & Pooled & Manufacturing & Services \\
\hline Earnings Smoothing & $-2.94(2.99)$ & $1.49(1.04)$ & $-35.88(13.32)^{*}$ \\
ROA & $-2.54(2.09)$ & $-1.19(.752)$ & $-5.21(4.71)$ \\
ROS & $-.439(.326)$ & $-.094(.085)$ & $-.847(.569)$ \\
EBITDA & $.189(.126)$ & $.957(.233)^{*}$ & $.379(.118)^{*}$ \\
$\lambda$ & $-.008(.001)^{*}$ & $-.004(.001)^{*}$ & $-.012(.004)^{*}$ \\
$\lambda(t x)$ & $.236(.183)$ & $-.201(.228)$ & $2.36(.866)^{*}$ \\
& & & \\
\# of obs. & 24,160 & 18,861 & 5,299 \\
$\mathrm{R}^{2}$ & .1115 & .0495 & .3031 \\
F-statistics. & $18.96(0.0000)^{*}$ & $12.56(0.0000)^{*}$ & $150.900 .0000)^{*}$ \\
\hline
\end{tabular}

\section{Conclusion}

Though earnings opacity has been documented in the past literature, it has not been clear whether earnings opacity is accurately and timely reflected in equity valuation. It is a well-known stylized fact that the accounting standards (i.e. US GAAP) allows divergent accounting revenue generating processes based on industry classification (i.e. industry 
specific accounting treatments). For example, by nature of the transactions, revenue recognition within the services industry in certain circumstances substantially differs from their manufacturing counterparts. Therefore this paper attempts to shed light on this issue by exploring the link between earning opacity and equity markets for a panel of firms within manufacturing and services industry. The two characteristics of equity markets that I explore are the total market capital capitalization and the market return for manufacturing and services industry. The two dimensions of earnings opacity (i.e. accruals and earnings smoothing) are measured directly from the financial statements obtained from compustat database. The empirical results overall shows that that on average, an increase in earnings opacity is linked to an increase in market value for firms within the manufacturing industry. In contrast, the results shows that on average, an increase in earnings opacity leads to a decrease in market value for firms within the services industry. Consequently, the results suggest that investors in services firms appear to have detected accurately and timely an occurrence of earnings opacity and in contrast, investors in manufacturing firms appears to have inaccurately and untimely uncover the occurrence of earnings opacity. Furthermore, the results suggest that firms utilize both dimensions of earnings opacity in a sustained manner as implied by the coefficients on time-trend and the interaction of time-trend and earnings opacity

\section{References}

Ali, A., \& L-S. Hwang. (2000). Country-specific factors related to financial reporting and the value relevance of accounting data. Journal of Accounting Research, 38, 1-21. https://doi.org/10.2307/2672920

Ashbaugh, H., \& Pincus, M. (2001). Domestic Accounting Standards, International Accounting Standards, and the Predictability of Earnings. Journal of Accounting Research, 39, 417-434. https://doi.org/10.1111/1475-679X.00020

Ball, R., Kothari, S.P., \& Robin, A. (2000). The effect of international institutional factors on properties of accounting earnings. Journal of Accounting and Economics, 29, 1-51. https://doi.org/10.1016/S0165-4101(00)00012-4

Barth, M. E., \& Kallapur, S. (1996). The effects of cross-sectional scale differences on regression results in empirical accounting research. Contemporary Accounting Research, 13, 527-567. https://doi.org/10.1111/j.1911-3846.1996.tb00514.x

Barth, M. E., Beaver, W. H., \& Landsman, W. R. (1998). Relative valuation roles of equity book value and net income as a function of financial health. Journal of Accounting and Economics, 25, 1-34. https://doi.org/10.1016/S0165-4101(98)00017-2

Barth, M. E., J. A. Elliott, \& M. W. Finn. (1999). Market rewards associated with patterns of increasing earnings. Journal of Accounting Research, 37(Autumn), 387-413. https://doi.org/10.2307/2491414

Bekaert, G., \& Harvey, C.V. (2000). Foreign speculators and emerging equity markets. Journal of Finance, 55(2), 565-613. https://doi.org/10.1111/0022-1082.00220 


\section{MlMacrothink}

International Journal of Accounting and Financial Reporting ISSN 2162-3082 2018, Vol. 8, No. 1

Bhattacharya, U., Daouk, H., \& Welker, M. (2003). The world price of earnings opacity. Accounting Review, 78(3), 641-678. https://doi.org/10.2308/accr.2003.78.3.641

Brennan, M. J., \& Cao, H. H. (1997). International portfolio investment flows. Journal of Finance, 52(5), 1851-1880. https://doi.org/10.1111/j.1540-6261.1997.tb02744.x

Chang, J. J., T. Khanna, \& K. G. Palepu. (2000). Analyst activity around the world. Working paper, The Wharton School of the University of Pennsylvania, Philadelphia, PA. https://doi.org/10.2139/ssrn.204570

Chen, P., \& Zhang, G. (2007). How do accounting variables explain stock price movements? Theory and evidence. Journal of Accounting and Economics, 43, 219-244. https://doi.org/10.1016/j.jacceco.2007.01.001

Christie, A. A. (1987). On cross-sectional analysis in accounting research. Journal of Accounting and Economics, 9, 231-258. https://doi.org/10.1016/0165-4101(87)90007-3

DeGeorge, F., Patel, J., \& Zeckhauser, R. (1999). Earnings manipulation to exceed threshold. Journal of Business, 72, 1-33. https://doi.org/10.1086/209601

Dye, R. A., \& Sridhar, S. S. (2008). A positive theory of flexibility in accounting standards. Journal of Accounting and Economics, 46(2-3), 312-333. https://doi.org/10.1016/j.jacceco.2008.09.002

Easton, P. D., \& Harris, T. S. (1991). Earnings as an explanatory variable for returns. Journal of Accounting Research, 29, 19-36. https://doi.org/10.2307/2491026

Fama, E. F., \& French, K. R. (1992). The cross-section of expected stock returns. Journal of Finance, 47, 427-465. https://doi.org/10.1111/j.1540-6261.1992.tb04398.x

Fudenberg, D., \& J. Tirole. (1995). A theory of income and dividend smoothing based on incumbency rents. Journal of Political Economy, 103, 75-93. https://doi.org/10.1086/261976

Gehrig, T. (1993). An information based explanation of the domestic bias in international equity investment. Scandinavian Journal of Economics, 95, 97-109. https://doi.org/10.2307/3440137

Healey, P., \& J. Wahlen. (1999). A review of the earnings management literature and its implications for standard setting. Accounting Horizons, 13, 365-383. https://doi.org/10.2308/acch.1999.13.4.365

Healy, P. (1985). The effect of bonus schemes on accounting decisions. Journal of Accounting and Economics, 7, 86-107. https://doi.org/10.1016/0165-4101(85)90029-1

Heath, C., \& Tversky, A. (1991). Preference and belief: ambiguity and competence in choice under uncertainty. Journal of Risk and Uncertainty, 4, 5-28. https://doi.org/10.1007/BF00057884 


\section{MInstitute ${ }^{\text {Mut }}$}

International Journal of Accounting and Financial Reporting

ISSN 2162-3082

Kothari, S. P., \& Shanken, J. (2003). Time-series coefficient variation in value-relevance regressions: A discussion of Core, Guay, and Van Buskirk and new evidence. Journal of Accounting and Economics, 34, 69-87. https://doi.org/10.1016/S0165-4101(02)00091-5

Kothari, S., \& Robin, A. (2000). Corrigendum to the effect of accounting earnings. Journal of Accounting and Economics, 29, 1-51.

Land, J., \& M. Lang. (2002). Empirical evidence on the evolution of international earnings. The Accounting Review, 77(Supplement), 115-133. https://doi.org/10.2308/accr.2002.77.s-1.115

Leuz, C., Nanda, D., \& Wysocki, P.D. (2003). Earnings management and investor protection: an international comparison. Journal of Financial Economics, 69, 505-527. https://doi.org/10.1016/S0304-405X(03)00121-1

Mark, F., Kristine W. H., \& Jason, S. (2011). Cash flows and leverage adjustments. Journal of Financial Economics, 103(3), 632-646.

Portes, R., Rey, H., \& Oh, Y. (2001). Information and capital flows: The determinants of transactions in financial assets. European Economic Review, 45, 783-796. https://doi.org/10.1016/S0014-2921(01)00138-6

Rangan, S. (1998). Earnings management and the performance of seasoned equity offerings. Journal of Financial Economics, $101-122$. https://doi.org/10.1016/S0304-405X(98)00033-6

Shivakumar, L. (2000). Do firms mislead investors by overstating earnings before seasoned equity offerings?. Journal of Accounting and Economics, 29, 339-371. https://doi.org/10.1016/S0165-4101(00)00026-4

Teoh, S. H., I. Welch, \& T. J. Wong. (2002). Why do new issues and high-accrual firms underperform: the role analysts' credulity. Review of Financial Studies. https://doi.org/10.1093/rfs/15.3.869

Trueman, B., \& S. Titman. (1988). An explanation for accounting income smoothing. Journal of Accounting Research, 26(Supplement), 127-139. https://doi.org/10.2307/2491184

\section{Copyright Disclaimer}

Copyright for this article is retained by the author(s), with first publication rights granted to the journal.

This is an open-access article distributed under the terms and conditions of the Creative Commons Attribution license (http://creativecommons.org/licenses/by/4.0/) 